\title{
Suffering and defense in work in a mental health care service
}

\author{
Sofrimentos e defesas no trabalho em um serviço de saúde mental \\ Sufrimientos y defensas en el trabajo en un servicio de salud mental
}

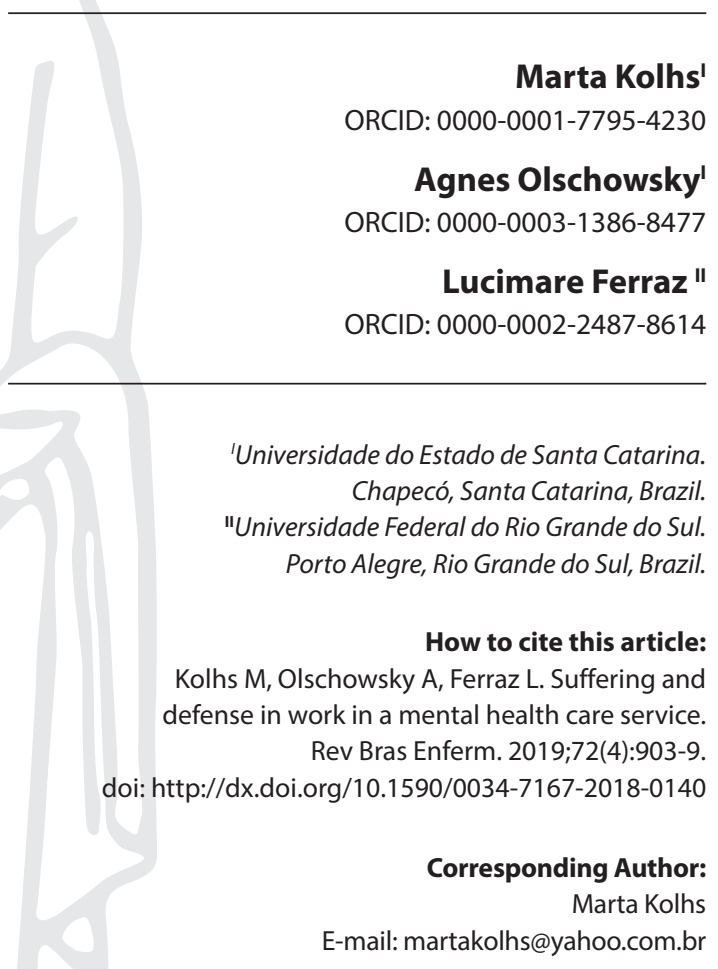

Submission: 04-24-2018 Approval: 08-18-2018

\begin{abstract}
Objective: to know the suffering and the strategies of defense of CAPS AD III workers, from the perspective of the Work Theater proposed by Dejours. Method: a descriptive qualitative research, of the case study type, with CAPS AD III workers, using as theoretical framework the Psychodynamics of Work. Results: CAPS AD III professionals identify that the suffering in the work arises from the frustration between the real and the prescribed one; by the hegemony of practices guided by the biomedical model; stigmatization and prejudice with users; and the limitations of the Health Care Network (Rede de Atenção à Saúde). As an individual defense strategy, the rationalization was defined, and as a collective strategy, the protection strategy. Final considerations: worker uses strategies of defenses to face suffering and give a new meaning to it, characterizing themselves as ways of apprehending, understanding and giving meaning and new looks to their work.

Descriptors: Mental Health; Occupational Health; Adaptation, Psychological; Health Services; Psychological Stress.
\end{abstract}

\section{RESUMO}

Objetivo: conhecer o sofrimento e as estratégias de defesa dos trabalhadores que atuam em um CAPS AD III, sob a perspectiva do Teatro do Trabalho proposto por Dejours. Método: pesquisa qualitativa descritiva, do tipo estudo de caso, com trabalhadores do CAPS AD III, usando como referencial teórico a Psicodinâmica do Trabalho. Resultados: os profissionais que atuam no CAPS AD III identificam que o sofrimento no trabalho surge pela frustração entre o real e o prescrito; pela hegemonia das práticas orientadas pelo modelo biomédico; pela estigmatização e o preconceito com os usuários; e pelas limitações da Rede de Atenção à Saúde. Como estratégia de defesa individual, definiuse a racionalização, e como estratégia coletiva, a de proteção. Considerações finais: o trabalhador utiliza estratégias de defesas para enfrentar o sofrimento e ressignificálo, caracterizando-se como modos de apreender, compreender e dar sentidos e novos olhares para o seu trabalho.

Descritores: Saúde Mental; Saúde do Trabalhador; Adaptação Psicológica; Serviços de Saúde; Estresse Psicológico.

\section{RESUMEN}

Objetivo: conocer el sufrimiento y las estrategias de defensa de los trabajadores que actúan en un CAPS AD III, bajo la perspectiva del Teatro del Trabajo propuesto por Dejours. Método: investigación cualitativa descriptiva, del tipo estudio de caso, con trabajadores del CAPS AD III, usando como referencial teórico la Psicodinámica del Trabajo. Resultados: los profesionales que actúan allí identifican que el sufrimiento en el trabajo surge por la frustración entre lo real y lo prescrito; por la hegemonía de las prácticas orientadas por el modelo biomédico; por la estigmatización y el prejuicio con los usuarios; y por las limitaciones de la RAS. Como estrategia de defensa individual se definió la racionalización, y como estrategia colectiva, la de protección. Consideraciones finales: el trabajador se utiliza de estrategias de defensa para enfrentar el sufrimiento y resignificarlo, caracterizándose como modos de aprehender, comprender y dar sentidos y nuevas miradas para su trabajo.

Descriptores: Salud Mental; Salud del Trabajador; Adaptación Psicológica; Servicios de Salud; Estrés Psicológico. 


\section{INTRODUCTION}

Suffering at work verified by the anxieties, fears and insecurities, is configured as an experience of painful experiences to workers. However, the presence of suffering does not imply a pathology - not being contrary to health, since the binomial pleasure-suffering can coexist in work situations ${ }^{(1)}$. However, excessive and constant suffering can bring a series of negative consequences to workers, such as illness, which consequently generates the loss of their working capacities and, even, the withdrawal of professional activities ${ }^{(2)}$.

The Psychodynamics of Work, theoretical framework adopted for this study, is concerned with the subject's relations in the collective, having as main aspect the defensive processes and condoms against suffering at work, considering the unique history of the worker and the current history of his work ${ }^{(3)}$. In addition, it analyzes the relationships among workers, the experiences of suffering and pleasure at work, perceiving the role of subjectivity and the defensive strategies built by workers themselves in the spaces where they work ${ }^{(3-4)}$.

Dejours exposes that suffering affects the worker's life in a structured way, and can be analyzed by the elements that make up a theater of work. According to the author, the work environment is the theater, with its characters (coordinators, managers, supervisor, co-worker), plot (the power structure and hierarchy, prejudices, values), setting (macroenvironment, unemployment, instability, uncertainties); and even spectators (family, friends, users, opponents) who, after all, will applaud or not, in an analogy with real life, the fruit of a life, approving it or not ${ }^{(3-4)}$.

In work environments, sometimes the worker suffers, but also has the resources and strategies to transform the painful feeling - in a creative and mature way - into job satisfaction ${ }^{(5)}$. To do so, it is necessary to re-characterize the elements that generate suffering, and this depends on the quality of the work dynamics and the defensive strategies that the worker uses ${ }^{(1)}$. In these cases, the subjectivity of the worker must be analyzed, thus evidencing the ways of coping with individual and collective suffering at work, since the Psychodynamics of Work is concerned with a comprehensive dynamics, turning to work organization and relationships among workers ${ }^{(3)}$. The analysis of defense strategies makes it possible to understand the domain of normality about mental illness in work contexts marked by adversities, revealing that workers do not become passive, but seek resources to deal with suffering and avoid the decompensation ${ }^{(1)}$.

Bringing to the context of mental health, a survey carried out with workers from a CAPS AD, several were the workers' reports about the exhausting effect when welcoming the user in that place, as well as the frustration and the fear in front of the crises of users, full of offenses and aggressiveness ${ }^{(6)}$. These reports are possible generators of psychological suffering to workers, a concept adopted by Dejours, aiming at a better understanding of pain and suffering ${ }^{(4)}$.

In view of the above, the present study consists of knowing suffering and defense strategies of workers from Centro de Atenção Psicossocial Álcool e Drogas III (Psychosocial Care Center for Alcohol and Drugs III), through the elements of the Theater of Work, from the perspective of Theory of Psychodynamics of Work.

\section{OBJECTIVE}

The objective of the study is to know suffering and defense strategies of workers that work in a Centro de Atenção Psicossocial Álcool e Drogas III (Psychosocial Care Center for Alcohol and Drugs III), from the perspective of the Theater of Work proposed by Dejours.

\section{METHODS}

\section{Ethical aspects}

This research followed the legal procedures required for research involving human beings, in accordance with Resolution $466 / 12$. Firstly, a request for agreement and consent was sent to the Municipal Health Office of Chapecó. In the possession of this authorization, the project was sent to the Research Ethics Committee (REC) of the Universidade do Estado de Santa Catarina (UDESC).

\section{Type of study and theoretical framework}

This is a descriptive qualitative research, of the type of case study, and that has as theoretical framework the Psychodynamics of Work. It is a cut of the qualitative research "Prazer e Sofrimento dos Trabalhadores que Atuam em um Centro de Atenção Psicossocial Álcool e Drogas III" (freely translated as Pleasure and Suffering of workers from a Psychosocial Care Center for Alcohol and Drugs III) ${ }^{(7)}$.

\section{Study setting}

The research was developed in the CAPS AD III of the municipality of Chapecó, SC, inaugurated in the psychosocial care network in 2009 and instituted in CAPS AD III in August 2013. It is a service designed to assist people with problems related to the use of psychoactive substances that operate 24 hours a day. The physical structure of CAPS AD III is an administrative, clinical and office space. There are 10 host/detox beds where the user stays at maximum for 14 days within 30 days according to the clinical picture and the indication of the team. Among the activities developed are: therapeutic, educational, mutual aid, individual care/therapy, reception, home visits, among other activities established for users in this service, according to the Plano Terapèutico Singular (PTS - is a set of proposals of articulated therapeutic behaviors, for an individual or collective subject).

\section{Data source}

CAPS AD III staff consists of 33 workers distributed between the middle level (nursing assistant, waitress, receptionist and vigilantes) and higher (general practitioner and psychiatrist, nurse, psychologists, occupational therapist, social workers, nutritionist, physical educator and educator).

In order to participate in the research, the following inclusion criteria were considered: being a worker linked to the service, being 18 years old or older and working in CAPS AD III for more than six months at the time of data collection. The exclusion criteria were: workers who were on vacation or leave at the time of data collection. Thus, participants were 23 workers, among them: nurses, nursing assistants, physicians, psychologists, pedagogues, 
caretakers, waitresses, occupational therapists, social workers and administrative technicians. Each worker was identified in the search by the letter W (worker) followed by an ordinal number (W1, W2...).

\section{Collection and organization of data}

For the information collection, individual interviews were conducted, according to the availability of each interviewee. All interviews took place in the workplace, in a reserved room. Dates and times were arranged directly with the participants after invitation and clarifications. The interviews were guided by a semi-structured instrument, with the triggering question:"Talk about your work at CAPS AD III". For recording, after the consent of the interviewee, an audio recorder was used. Following the collection of information, the interviews were transcribed in full. Individual interview technique was chosen due to the characteristics and organization of the service, and to the distribution of workers in shifts, rendering group processes of investigative approach unfeasible.

\section{Data analysis}

The information obtained was analyzed through content analysis, organized in three phases: pre-analysis; exploitation of the material; treatment of results, inference and interpretation ${ }^{(8)}$. The stage of analysis of the results is the phase in which condensation occurs and the information is highlighted, culminating in inferential interpretations in a reflexive and critical way, articulating the objectives of the study with the theoretical basis adopted ${ }^{(8)}$. In this study, the theoretical basis adopted was the Psychodynamics of Work.

\section{RESULTS}

The results of this study are presented on the basis of the elements that make up the "Theater of Work", namely: characters (CAPS AD III workers); plot (the working process in CAPS AD III); the viewers (users and family) and setting (CAPS AD III macroenvironment) ${ }^{(3)}$.

\section{Characters: frustration between the real and the prescribed at work at CAPS AD III}

The real work at CAPS AD III, for several moments, proves to be frustrating to the worker, generating a feeling of failure, impotence and discouragement when the result of his work does not correspond to the efforts and investments of care with users.

The results of our work, the coming and going of users [relapse], frustrates me. I do not see the positive result, the improvement to encourage me [...] (T8)

I see that some teammates are not accomplished [...] do not understand their role and much less the service to these users [...] (T13)

Families do not understand disease/dependence [...] do nothelp thefamily/user to comply with the treatment, howevermuch weadvise [...] (T5)

It is observed that the worker mobilizes his subjectivity and his technical knowledge to circumvent tense situations of suffering, together with the familiar and users.

\section{Plot: biomedical model $t$ work at CAPS AD III}

Despite the advances promoted by the Psychiatric Reform, the biomedical model is still strongly practiced in CAPS AD III. This model is based on the traditional understanding of mental suffering, on the power of medical knowledge, which is based on prescription drugs, that is, the exchange of one drug for another.

I see the service very focused on the medical consultation, the therapy cannot and should not be focused on the physician. The dynamics of CAPSADIII is not for this, but in the team in different groups, workshops and in the individual if necessary. (W19)

[...] the team focuses the care in the medical consultation, in the welcoming. Almost all users are directed to the medical consultation, overloading the schedule [...] damage reduction is not a team practice. (W16)

We are a multidisciplinaryteam and offervarious forms of care for users, such as groups, workshops, psychotherapy, among others, but the user always asks for the medical consultation, by the medication [...] (W17)

Biomedical practice deprives the service and the interdisciplinary work, generating a feeling of frustration in workers. In a way, there is a feedback between the biomedical model and the team frustration in the interdisciplinary action.

\section{Television viewers: stigmatization and prejudice with users}

CAPS AD III workers report the daily experience of prejudice and stigma, since users live socially marginalized, preventing and hindering their inclusion in different spaces and sectors.

When we refer or solicit something from other public sectors of the City Hall, I clearly realize that it sticks to prejudice [...].Society has a lot of prejudice with the user and the service. Denominate treatment service for drunkards, vagabonds, degenerates [...].We face difficulty until the user wants to go back to school, but the school says that there is no vacancy, when we know that this is not true, there is a strong exclusion from this population [...] (W13)

Society does not believe and exclude users. We must welcome and believe in a new possibility [...] (W21)

Besides addiction, there is the social problem. Society pushes for addiction, relapses, feeds addiction, while recriminating, discriminating and stigmatizing, this hypocrisy makes me sick! (W18)

It is perceived that the CAPS AD III worker suffers from the prejudice that society has with the user. However, the deviation between what is prescribed (what is right of the user) and the real (prejudice) also exists among service workers themselves.

The poor understanding of colleagues towards the user bothers me, the way he deals with what he talks to the user, improper, biased, authoritarian comments [...] (W12)

The lack of ethics [of the CAPS workers] and prejudice is something that bothers me. (W21)

The purpose of care in CAPS AD III should be guided by the reconstruction of the life of the user beyond the health-disease 
circuit. Working at this health service also means rescuing selfesteem and promoting the social reintegration of users, making the clash, in this course, with the prejudice and stigma imposed on dependents of psychoactive substances.

\section{Setting: Health Care Network (RAS - Rede de Atenção à Saúde) limitations}

Health Care Networks (Redes de Atenção à Saúde) are defined as organizational arrangements for health actions and services of different technological densities, which are integrated through technical, logistical and management support systems, seeking to guarantee the comprehensiveness of care. Operationalization of a care network and the development of actions extended to the wider social space have encountered impasses, which, according to the reports of the CAPS AD III workers, cause anguish and suffering.

BHU/FHS teams say they are not prepared to work with families and not even with users [...] this is bothering. (W16)

We cannot release users because primary care says they cannot follow up. (W19)

School workers, social service, and basic health care, argue that they have no structure or staff to continue treatment in the community where users live [...] (W2)

Insertion of practices with psychoactive substances users and family in primary care proves the search for the regionalization and redirection of care, in the logic of comprehensive and humanized care for users, in articulation with workers and services already inserted in the territories.

\section{STRATEGIES OF SUFFERING DEFENSE STRATEGIES IN THE THEATER OF WORK AT CAPS AD III}

\section{Strategies of individual defense: reasoning}

As a way to confront the unknown, the new, some service workers individually seek improvement and learning in order to adapt to the norms, politics and demands of users. Workers pointed to using the strategy of rationalization as allies for the relief of their suffering. By using these strategies, they "relax" from work, compensating for leisure activities and other skills that give them pleasure.

The first months of work were suffered and challenging because of entering a new policy, I went to study, to read [...] today, if I have difficulty, I continue to use reading [...] (W9)

I was afraid at first, but I was letting myself go, listening, and seeing that the user is just like any other, but with different demands [...] today, when I become insecure, I reflect on the situation [...] (W10)

It is exhausting to work with this public, it leaves here well, returns very relapsed [...]but I think "I'm glad I can help, I'm on the other side". (W6)
The use of individual defense strategies by CAPS AD III workers constitutes another alternative that they use to face the experiences of suffering and re-signify it. CAPS AD III workers use reasoning as a defense to understand suffering of their work by giving meaning to their experiences. The worker attributes a social value to the work, seeking to minimize the impact of the stressors involved in his work in CAPS AD III.

\section{Strategies for collective mobilization: protection}

CAPS AD III workers, faced with the experiences of suffering, even being individuals, are associated, identified, empathic with colleagues, supported as a protection strategy. Collective protection mobilization strategies are related to the way workers think, feel and act as compensators ${ }^{(8)}$. They appear as a strategy of collective defense, levitation, euphemism of anguish, fear and insecurity at work ${ }^{(8)}$. Therefore, it is through these strategies that CAPS AD III workers manifest modify, transform or minimize the perception of reality that bothers them and makes them suffer.

Ifeel relieved in exchanges and conversations with other colleagues, having coffee in the kitchen [...] (W14)

Relations with colleagues, discussion, exchanges and outbursts are very good. [...] we are always moving to change what we understand is not appropriate or that bothers us. (W11)

When we have tense situations at work, we help each other [...], we talked, we reflected on behaviors, attitudes [...], we support and protect each other. (W12)

Another device for coping with suffering is team meetings. At that moment, CAPS AD III workers expose, debate and think about ways to overcome this feeling.

\begin{abstract}
The team meeting is a free space, where we can talk, suggest, complain and organize ourselves. I find this space very good and profitable. (W6)

[...] we can talk, discuss situations, ask for help, reflect, study together to better serve the user, and also to reduce our anguish [...], understand and share in team that users are free subjects. (W19)
\end{abstract}

Team meetings in CAPS AD III are characterized as a space where the worker can express himself, listen, make exchanges, establish cooperation ties and protection strategies with other colleagues. It should be noted that the service team has been organized, since 2013, to close its door to external service, once a week, so that all workers participate in the meeting.

\section{DISCUSSION}

It is recognized as a factor of suffering the idealization that workers have over work, that is, they believe that work occurs only in a prescribed way, or even idealized and they feel distressed when they perceive that they do not account for the reality of the job. Working at CAPS AD III requires much more than technical/ scientific knowledge; the real work is revealed in the social needs 
of the user as: food, housing, work, leisure, affective relationships, among others, situations where the prescribed does not correspond to the real.

Given this setting, it is possible to recognize suffering of the CAPS AD III worker in front of the (prescribed) idealization and the (real) frustration. When workers are faced with the gap between the prescribed and the real, they experience the sense of failure and experience suffering of not knowing how to do ${ }^{(2)}$. Initially they adopt a passive position, sometimes marked by anger and discouragement, but to overcome these painful situations they need to act, which includes the capacity to tolerate suffering and make new attempts, until finding them or creating a solution ${ }^{(1-2)}$.

Suffering of workers is invisible, that is, it is not something measurable, and only becomes visible and accessible by speech at the moment when the worker names what he feels ${ }^{(9)}$. The authors also say that suffering itself should not be understood as pathology, but as a warning sign for some kind of action to be mobilized. Working is to continue indefinitely to seek, to recommence and, above all, to find solutions to the real work ${ }^{(1)}$.

Psychiatric Reform guidelines point out that the CAPS should constitute spaces for a differentiated care, in which the principle of the deinstitutionalization of the assistance is materialized from a clinical practice centered on the subject/user and their care needs. It is necessary to have a deconstruction of the concept of mental illness from the biomedical reference. In addition, there must be the adoption of a new way of perceiving suffering as the existence-suffering of the subject in his relationship with the social body ${ }^{(10)}$.

Participation in a CAPS AD III implies the construction of workers themselves, the reformulation of paradigms related to old forms of care in Mental Health and a new form of relationship with users, closer and without the instruments of protection and punishments of traditional psychiatric services ${ }^{(11)}$.

However, in the field of Mental Health with specificity for alcohol and drugs, it will often not be possible to respond to this tradition and expect immediate ${ }^{(12)}$, as the biomedical model still prevails in care and assistance in CAPS AD III.

In order for CAPS AD III workers to be able to reintegrate the user, the orientation is to act in the territory (geographic, political, economic and cultural), in order to develop partnerships with the various resources existing in the community, enabling the work in an intersectoral way. The existing facilities in the territory, besides the health care network, are services that consist of the secretariats of education, culture, environment, civil associations, philanthropic institutions, companies, partners, in general, that can contribute to the inclusion of psychoactive substance users ${ }^{(13)}$. Therefore, work in CAPS AD III requires intersectoral actions, which are based on the articulation of knowledge, implementation and evaluation of actions, in order to obtain a cohesion effect in complex situations, aiming at social development, in order to overcome the prejudice and, consequently, the social exclusion to which SPAs users are exposed ${ }^{(14-15)}$.

It is pointed out the importance of matricial practice as a strategy in Mental Health because besides increasing the resolvability, it allows an approximation between the CAPS and the FHS, increasing the potential of these services as agents of new modes of care in Mental Health ${ }^{(16-17)}$.
Suffering of CAPS AD III workers is recognized in view of the limitations of the RAS. However, these CAPS AD III professionals seek to find alternatives in a team for the reinsertion of the user into society (schools, work, community, family ties, etc.), giving them autonomy and co-responsibility in care for family. Faced with this reality, they mobilize their internal resources and put their creativity into action; there is then an intelligence guided by suffering (practical intelligence), for it is through suffering established from the solution to that which causes anguish ${ }^{(1-2)}$.

Another aspect that causes suffering to CAPS AD III workers is the prejudice and stigma that society has regarding users of this service. Prejudice is understood as a premature and improper judgment on the use of drugs, that is, a negative and inflexible attitude, defined to something or someone, constructing an idea without previous knowledge ${ }^{(18)}$. However, stigma evidences something that exceeds an attitude of prejudice, as a sign of desprestige, unworthy and dishonorable, a mark in honor of someone, who suggests contamination ${ }^{(19)}$. It is evidenced that society stigmatizes psychoactive substances users when it characterizes them as a sign or a mark of "deteriorated", therefore, less valued than the "normal".

Thus, from a perspective of prejudice, it is no longer considered who makes use of psychoactive substances, specifically alcohol and illicit drugs as an "ordinary person, reducing her to a spoiled and diminished person, that is, to stigmatize and exclude her, especially when the effect of discrediting her is great"(18).

To overcome this situation, CAPS AD III workers must be open to change, in order to break with the concepts imposed by the society of which it is a part, in relation to psychoactive substances users. On the other hand, some workers may find it difficult to adapt to this work setting by bringing with them a life history that can emerge in the face of the singularity of each user and the adversities that the work in that service brings. These adversities can be viewed and processed by workers in a positive and/ or negative way.

Suffering defense strategies, also called defensive strategies, can be defined as resources constructed by workers, collectively and individually. These strategies aim to minimize the perception of suffering at work and work by refusing to perceive what causes suffering to workers ${ }^{(20)}$. Euphemization of suffering provides the psyche with a protection that makes it possible for workers to remain on the normality dimension, in order to continue working ${ }^{(20)}$.

The defensive strategies used by CAPS AD III workers are marked by rationalization as an individual strategy and by collective protection. Both strategies manifest in the worker the subtlety, ingenuity, diversity and inventiveness, causing suffering to be supported and/or re-signified ${ }^{(2)}$.

Individual defense strategies are mechanisms that workers use, often unconsciously, to deny their own suffering and suffering of others at work, or to rationalize suffering and human cost at work $^{(21)}$. These defensive strategies, even occasionally used, are social and cultural practices implanted from relationships with others. Individual tactics gain strength when the collective is frail. With the weakening of the collective of work, the individual strategy of rationalization of suffering is increasingly demanded, being a coping mechanism of suffering generated by the alienating dynamics of labor organizations ${ }^{(22)}$. 
In turn, the strategy of collective mobilization is in the way workers organize themselves together, when there is the common goal of eliminating the negative cost that labor imposes on them. With this, they allow to arrive at a common denominator, that is, a public space of discussion so that they can express collectively their suffering ${ }^{(22)}$. Relations of the collective appear as central in the defense of suffering. They are expressed in the production of affection and resistance in their organization. This is because you work not only for yourself, but also for others ${ }^{(23)}$, therefore the importance of collective mobilization strategies, aiming at the emancipation and freedom of workers ${ }^{(24)}$. In this sense, the importance of work organization is highlighted, which, in order to be beneficial and generate pleasure for workers, requires an environment that enables freedom, recognition and horizontal relations at work ${ }^{(25)}$.

The premise of Dejours' Psychodynamics of Work is the idea that when there is fragility of the worker's subjective equilibrium, this individual will have collective defensive postures, since the group reinforces the values and manly representations of the subjects $^{(26)}$. Dejours affirms that effective cooperation implies a deontic activity, that is, a collective activity of producing rules of work and agreements among workers ${ }^{(27)}$. In other words, the same gap that affects individual work - between the prescribed and the real - also affects collective work. In this case, cooperation among workers, which initially revolves around technical issues, is also empathetic, developing trust in each other to share tricks and secrets they employ to perform tasks and to protect against suffering ${ }^{(26)}$.

However, when this worker feels scared, worn, sick, useless and helpless, this state affects his ability to act and collaborate in the production of the other's sense of life. Such a condition of impotence is expressed in interpersonal and intersubjective relations, proving the need to think about care for the worker, because when he experiences his work with pleasure, he develops a greater production of bond; otherwise, when he is exhausted, he has difficulties in feeling empathy in the face of his colleague's suffering ${ }^{(6)}$.

\section{Study limitations}

It should be recognized that the study has limits to not include a greater diversity of CAPS AD III and other modalities of CAPS in the research. Therefore, the results cannot be generalized to other intersectoral care network services. In addition, it is accepted that the use of the method of individual interviews may have been a limiting factor, since interviews in the collective environment could have provided the discussion and the reflection of workers, besides an exchange of knowledge and strategies of protection to the situations of suffering at work.

\section{Contributions to the fields of Nursing and Mental Health}

The contribution of the study is to unveil the Psychodynamics of Work in the CAPS AD III, evidencing that workers, among them nurses, who work in this service of Mental Health care, also go through moments of suffering. In this way, this caregiver also needs to be taken care of. It is understood that the study contributes to (re)think protective actions, from a perspective focused on the subjectivity of these workers.

\section{FINAL CONSIDERATIONS}

The study shows that CAPS AD III workers have the feeling of suffering triggered when they are frustrated by not having an expected outcome in the care given to their patients; and when they realize how much the real is distant from the prescribed one, and that the treatment is still very focused on the biomedical model, the medicalization, and not the preventive and collective work. They are dismayed by the prejudice and stigmatization that chemical dependents suffer from society in general and even from other health professionals. The reality of the lack of networking impairs the results of the prescribed care, causing suffering to CAPS AD III workers.

On the other hand, CAPS AD III workers develop strategies to defend against suffering. It is possible to emphasize from their testimonies, the rationalization of their work, in which in an individual process, they understand that the results of what is prescribed take time to become something real when it comes to chemical dependents. In addition, they use collective mobilization strategies, such as protection strategies, seeking ways to alleviate fears, anxieties, insecurities and solutions to the problems experienced in the service. The team meetings are the device for this practice most mentioned by workers.

By the results of the study, when using the defense strategies, be they individual, collective or both, it is observed that the workers seek to subvert the situations that generate suffering, evidencing also that there is satisfaction in working in CAPS AD III.

\section{FUNDING}

This study had funding from CAPES, in cooperation with Dinter (Doutorado Interinstitucional) - UDESC/UFRGS.

\section{REFERENCES}

1. Dejours C. Trabalho vivo: trabalho e emancipação (Tomo II). Brasília: Paralelo 15; 2012. 222 p.

2. Demaegdt C, Rolo D, Dejours C. Psychopathologie et psychodynamique du travail. EMC - Pathologie professionnelle et de l'environnement. 2013;8(3):1-11. doi: 10.1016/S1877-7856(13)58377-2

3. Dejours C. A loucura do trabalho: estudo de psicopatologia do trabalho. 6a ed. São Paulo: Cortez; 2015. 168 p.

4. Dejours C, Abdoucheli E. Itinerário teórico em psicopatologia do trabalho. In: Dejours C, Abdoucheli E, Jayet C. Psicodinâmica do trabalho: contribuições da escola Dejouriana à análise da relação prazer, sofrimento e trabalho. 16a reimp. São Paulo: Atlas; 2015. p. 119-45.

5. Dejours C. Psicodinâmica do trabalho: casos clínicos. Porto Alegre: Dublinense; 2017. 144 p. 
6. Wandekoken KD, Dalbello-Araujo M, Borges LH. Efeitos danosos do processo de trabalho em um Centro de Atenção Psicossocial Álcool e Drogas. Saúde Debate. 2017;41(112):285-97. doi: http://dx.doi.org/10.1590/0103-1104201711223

7. Kolhs M. Prazer e sofrimento dos trabalhadores que atuam em um Centro de Atenção Psicossocial álcool e drogas III [Tese]. Universidade Federal do Rio Grande do Sul; Porto Alegre. 2017.

8. Bardin L. L'analyse de Contenu. Collection: Quadrige . PUF; 2013. pages 304.

9. Mendes AM, Moraes RD, Merlo ARC. Trabalho \& Sofrimento: práticas clínicas e políticas. Curitiba: Juruá; 2014.

10. Amarante P. Saúde mental e atenção psicossocial. 4a ed. Rio de Janeiro: Fiocruz; 2015. 120 p.

11. Uchida S, Sznelwar LI, Barros JO, Lancman S. O trabalhar em serviços de saúde mental: entre o sofrimento e a cooperação. Laboreal [Internet]. 2011 [cited 2016 Oct 16];7(1):28-41. Available from: http://laboreal.up.pt/revista/artigo.php?id=48u56oTV65822353389453854:2

12. Brasilia: Ministerio da Saude; Saúde Mental no SUS: cuidado em Liberdade, Defesa de Direitos e Rede de Atenção Psicossocial. Relatório de Gestão 2011-2015. Brasilia: Ministerio da Saude; 2016, 143 p.

13. Ministério da Justiça e Cidadania (BR). Secretaria Nacional de Políticas sobre Drogas. O uso de substâncias psicoativas no Brasil: módulo 1. 10a ed. - Brasília; 2016. 146 p.

14. Ministério da Saúde (BR). Portaria n. 130, de 26 de janeiro de 2012. Redefine o Centro de Atenção Psicossocial de Álcool e outras Drogas $24 \mathrm{~h}$ (CAPS AD III) e os respectivos incentivos financeiros [Internet]. Brasília: Ministério da Saúde; 2012 [cited 2014 May 24]. Available from: http://bvsms.saude.gov.br/bvs/saudelegis/gm/2012/prt0130_26_01_2012.html

15. Garcia L, Santana P, Pimentel P, Tykanori RT. A Política Nacional de Saúde Mental e a Organização da Rede de Atenção - SUPERA. 10a ed. Brasília: Secretaria Nacional de Políticas sobre Drogas; 2016. (O uso de substâncias psicoativas no Brasil: módulo 1).

16. Lucchese R, Oliveira AGB, Conciani ME, Marcon SR. Saúde mental no Programa de Saúde da Família: caminhos e impasses de uma trajetória necessária. Cad Saúde Pública[Internet]. 2009[cited 2014 May 24];25(9):2033-42. available from: http://www.scielo.br/pdf/csp/v25n9/17.pdf

17. Dimenstein AKS, Monique M, Pimenta AL, Medeiros V, Bezerra E. O apoio matricial em unidades de saúde da família: experimentando inovações em saúde mental. Saúde Soc [Internet]. 2009[cited 2014 May 24];8(1):63-74. Available from: http://www.scielo.br/pdf/sausoc/ v18n1/07.pdf

18. Bard ND, Antunes B, Roos CM, Olschowsky A, Pinho LB. Estigma e preconceito: vivência dos usuários de crack. Rev Latino-Am Enfermagem [Internet]. 2016[cited 2014 May 24];24:1-7. Available from: http://www.scielo.br/pdf/rlae/v24/pt_0104-1169-rlae-0852-2680.pdf

19. Schilling Fl, Myiashiro SRG. Como incluir? o debate sobre o preconceito e o estigma na atualidade. Rev Educ Pesqui [Internet]. 2008[cited 2014 May 24];34(2):243-54. Available from: http://www.scielo.br/pdf/ep/v34n2/03.pdf

20. Moraes RD. Estratégias defensivas. In: Vieira FO, Mendes AM, Merlo ARC (Org.). Dicionário crítico de gestão e psicodinâmica do trabalho. Curitiba: Juruá, 2013; p. 153-58.

21. Kieling M, Monteiro J, Vieira FO, Mendes AM. Trabalho \& Prazer: teoria, pesquisas e práticas. Curitiba: Juruá; 2015. 264 p.

22. Anjos FBD, Mendes AM, Santos AV, Facas EP. Trabalho prescrito, real e estratégias de mediação do sofrimento de jornalistas de um órgão público. Rev Eletr Sistema Gestão [Internet]. 2011 [cited 2017 Feb 18];6(4):562-82. Available from: http://www.revistasg.uff.br/index.php/sg/ article/viewFile/V6N4A11/V6N4A11

23. Ferreira MC. Chegar feliz e sair feliz do trabalho: aportes do reconhecimento no trabalho para uma ergonomia aplicada à qualidade de vida no trabalho. In: Mendes AM (Org.). Trabalho e saúde: o sujeito entre a emancipação e a servidão. Curitiba: Juruá; 2010. p. 40-53.

24. Dashtipour P, Vidaillet B. Work as affective experience: the contribution of Christophe Dejours'"psychodynamics of work'. Organ. 2017;24(1):18-35. doi: https://doi.org/10.1177/1350508416668191

25. Gonçalves AM, Vilela SC, Terra FS, Nogueira DA. Atitudes e o prazer/sofrimento no trabalho em saúde mental. Rev Bras Enferm [Internet]. 2016[cited 2017 Feb 18];69(2):266-74. Available from: http://www.scielo.br/pdf/reben/v69n2/0034-7167-reben-69-02-0266.pdf

26. Deranty JP. Work as Transcendental Experience: Implications of Dejours' Psycho-dynamics for Contemporary Social Theory and Philosophy. Critical Horizons. 2010;11(2):181-220. doi: https://doi.org/10.1558/crit.v11i2.181

27. Dejours C. Le choix. Souffrir au travail n'est pas une fatalité, Paris: Bayard; 2015. 